\title{
Assessment of Genetic Parameters for Seed Cotton Yield Related Traits and Biochemical Parameters in Desi Cotton (Gossypium arboreum L.)
}

\author{
R. D. Vekariya ${ }^{1^{*}}$, S. Nimbal ${ }^{2}$, Aashima batheja ${ }^{3}$, Jay Prakash ${ }^{3}$, C. S. Patel ${ }^{1}$ and A. G. Singh ${ }^{1}$
}

${ }^{1}$ Dept. of Genetics and Plant Breeding, Navsari Agriculture University, Navsari (496 390), India

${ }^{2}$ Cotton Section, Dept. of Genetics and Plant Breeding, CCS Haryana Agriculture University, Hisar (125 004), India

${ }^{3}$ Dept. of Crop Improvement, CSK Himachal Pradesh Krishi Vishavidhalaya, Palampur, H.P. (176 062), India

\section{Corresponding Author}

R. D. Vekariya

e-mail: rajesh22vk@gmail.com
Article History

Article ID: 3ICBSM0119

Received in $26^{\text {th }}$ September, 2017

Received in revised form $4^{\text {th }}$ October, 2017

Accepted in final form $7^{\text {th }}$ October, 2017

\begin{abstract}
Desi cotton Gossypium arboreum has wide adaptability under rainfed situation and also high degree of resistance to biotic and abiotic stresses. Present investigation total sixty GMS based desi cotton $F_{1}$ hybrids along with complete set of nighteen parents and one checks were evaluated for variability, heritability and genetic advance in different yield and yield contributing traits. The treatment, i.e. mean sum of squares due to genotypes revealed significant differences for all characters studied, that revealing the presence of high genetic variability among the genotypes. The estimates of GCV were lower than the respective PCV; it means that the apparent variation is not only due to genotypes but also due to the influence of environmental factors on the expression of the traits studied. Characters like seed cotton yield/ plant, No. of bolls plant ${ }^{-1}$ and gossypol content showed high GCV, PCV, heritability coupled with high genetic advance as percent of mean, suggesting that selection for the improvement of these characters may be rewarding. High heritability estimates coupled with high expected genetic advance as percent mean were observed for the traits like, seed cotton yield plant ${ }^{-1}$, No. of bolls plant ${ }^{-1}$ and gossypol content, that indicating presence of additive gene effects in its inheritance and such characters could be improved by selection. Low heritability estimates with expected low genetic advance were observed for the traits like Lint index, boll weight boll ${ }^{-1}$ and seed index that also indicates greater role of non-additive gene action in their inheritance suggesting heterosis breeding could be useful for improving these traits.
\end{abstract}

Keywords: G. arboreum L., desi cotton, GCV, PCV, heritability, GA, GAM (\%)

\section{Introduction}

Cotton is sensitive to biotic and abiotic stresses and environment fluctuation, the wide range of agro-climate condition in which cotton grown in our country cause considerable influence on yield and quality. The cotton breeding policies have, therefore, to be reoriented, as per the need of growers, to develop widely adapted strains which withstand weather fluctuation and adverse condition. Diploid cotton Gossypium herbaceum and Gossypium arboreum has wide adaptability under rainfed situation and also high degree of resistance to biotic and abiotic stresses. For this purpose breeders are interested in development of superior cotton population with use of available genetic variability both indigenous as well as exotic to cater the need of various farming situations of cotton. The seed cotton yield is the primary trait targeted for improvement of cotton productivity in both favorable and unfavorable environments from its present level. The systematic breeding programme involves the steps like creating genetic variability, practicing selection and utilization of selected genotypes to evolve promising varieties. The large spectrum genetic variability in segregating populations depends on the level of genetic diversity among genotypes offer better scope for selection. Knowledge of the nature and magnitude of genotypic and phenotypic variability present in any crop species plays an important role in evolving superior cultivars. Importance of estimation of genotypic and phenotypic variability is formulating efficient breeding procedures in cotton have been emphasized by Hutchinson (1940); Miller et al. (1958). Many researchers studied the phenotypic and genotypic coefficients of variation were estimated using genotypic and phenotypic variances respectively (Do Thi et al., 2008; Kulkarni et al., 2011; Erande et al., 2014; Ranjan et al., 2014). The coefficient of variation indicated only the extent of existing variability for various traits, but does not give any information about the heritable portion of it. Therefore, heritability accompanied by estimates of genetic advance and genetic advance as per cent mean were also estimated. Heritability and genetic advance are other important selection parameters. Hanson et al. (1956) 
defined heritability in broad sense as the ratio of genotypic variance to the phenotypic variance in the non-segregating populations. Thus, heritability is the heritable portion of phenotypic variance. It is a good index of transmission of characters from parents to their offspring (Falconer, 1981). The estimates of heritability help the plant breeder in determining the character for which selection would be rewarding of elite genotypes from diverse genetic populations. The breeders are interested in selection of superior genotypes based on their phenotypic expression in stress and stress free environments. Heritability estimates along with genetic advance are normally more helpful in predicting the gain under selection than heritability estimates alone. Many investigations had studied heritability along with genetic advance for seed cotton yield and other traits (Dhamayanathi et al., 2010; Patnaik and Sial 2010; Ranjan et al., 2014; Erande et al., 2014 and Sunayana et al., 2017). Genetic advance measures the amount of progress that could be expected with selection in a character. However, character showing high heritability need not exhibit high genetic advance (Johnson et al., 1955). High heritability coupled with high genetic advance indicates the improvement could be made for a character by simple selection. Therefore, estimates of GCV, PCV, heritability and genetic advance will play an important role in exploiting future research projections of desi cotton improvement in both favorable and unfavorable environments.

\section{Materials and Methods}

Sixty $F_{1}$ hybrids along with complete set of nighteen parents (4 GMS based female parent and 15 male parent) and one standard checks (AAH 1) were evaluated during kharif, 2016 in RBD with three replications under optimal crop management practices at research area of Cotton section, Deptt. of Genetics and Plant Breeding, CCS Haryana Agricultural University, Hisar. Observations were recorded for thirteen characters namely, days to first flower, number of monopods, number of bolls per plant, plant height, boll weight, seed cotton yield plant ${ }^{-1}$, number of seeds boll ${ }^{-1}$, ginning out turn, seed index and lint index and biochemical parameters like oil content, protein content and gossypol content. The data was recorded on five randomly selected plants from each replication for ten quantitative characters and three biochemical parameters and the averages were used for analysis. The data recorded on the above fifteen characters were subjected to the following statistical analysis: Analysis of variance (ANOVA), variance and co-efficient of variance, heritability (broad sense) and genetic advance. Statistical analysis was carried out by using replicated data over sample plants through INDO STAT package.

\section{Results and Discussion}

The mean sum of squares due to genotypes showed significant differences for 13 characters studied among 80 genotypes (Table 1), indicating the presence of high genetic variability among the genotypes. The significant differences among the
Table 1: Mean Squares for thirteen characters under study in Gossypium arboreum L.

\begin{tabular}{|c|c|c|c|}
\hline Source of variation & Replication & Treatment & Error \\
\hline D.F & 2.00 & 79.00 & 15.28 \\
\hline Seed cotton yield plant ${ }^{-1}$ & 3.75 & $1182.50^{* *}$ & 10.36 \\
\hline No. of bolls & 69.33 & $247.78^{* *}$ & 0.01 \\
\hline Boll weight boll-1 & 0.02 & $0.04^{* *}$ & 1.33 \\
\hline No. of seeds boll-1 & 0.00 & $7.93^{* *}$ & 0.13 \\
\hline Seed index & 0.00 & $0.53^{* *}$ & 0.16 \\
\hline Lint index & 0.12 & $0.34^{* *}$ & 3.62 \\
\hline Ginning outturn & 0.30 & $18.95^{* *}$ & 0.26 \\
\hline No. of monopod & 0.46 & $0.99^{* *}$ & 83.00 \\
\hline Plant height & 10.06 & $4506.37^{* *}$ & 2.95 \\
\hline Days to first flower & 5.23 & $13.51^{* *}$ & 0.00 \\
\hline Gossypol content & 0.00 & $0.04^{* *}$ & 0.18 \\
\hline Oil content & 0.03 & $4.09^{* *}$ & 0.47 \\
\hline Protein content & 0.82 & $12.10^{* *}$ & 15.28 \\
\hline
\end{tabular}

${ }^{* *}$ Significant at $(p=0.01)$ levels

genotypes studied suggest that variability can be further utilized in crop improvement programme. The estimates of genetic parameters including genotypic variance, phenotypic variance, genotypic co-efficient of variation, phenotypic co-efficient of variation, heritability (broad sense), genetic advance and genetic advance as percent of mean (Table 2) deserve attention in deciding selection criteria for improvement in the concerned characters. High magnitude of variation in the experimental material was reflected by high values of mean and rang for almost all the characters. The observation recorded for seed cotton yield and related traits indicating the present of wide range of variation. Seed cotton yield exhibited wide variation ranged from $19.17 \mathrm{~g}-125.68 \mathrm{~g}$ with mean value $72.51 \mathrm{~g}$. High amount of PCV and GCV has been reported by Patnaik and Sial (2010) and Ranjan et al. (2014) for seed cotton yield. A perusal of heritability estimates indicated that seed cotton yield plant ${ }^{-1}$ had high heritability estimates. The genetic advance as well as genetic advance percentage of mean (GAM) was found to be the high for this trait. Similar findings of high heritability and high GAM were reported by Do Thi et al. (2008); Khan et al. (2009). Number of bolls plant ${ }^{-1}$ bears direct influence on seed cotton yield. The range observed for this trait was much wider, from 9.80-60.93 and mean value 35.67. Varying levels of differences in PCV and GCV have been observed for this trait in earlier studies on cotton by Khan et al. (2009); Ranjan et al. (2014). The heritability observed for this trait was higher (88.00\%) with higher GA (17.23) and GAM (48.12\%) indicating the predominance of additive genetic variance and hence simple selection alone will help to develop a good genotype. Similar result was reported by Kaushik and kapoor (2006) 
International Journal of Bio-resource and Stress Management 2017, 8(5):703-707

\begin{tabular}{|c|c|c|c|c|c|c|c|c|c|c|c|}
\hline \multirow[t]{2}{*}{ Traits } & \multirow[t]{2}{*}{ Mean $\pm S E$} & \multirow[t]{2}{*}{ Range } & \multicolumn{3}{|c|}{ variance } & \multirow{2}{*}{$\begin{array}{l}\mathrm{GCV} \\
(\%)\end{array}$} & \multirow{2}{*}{$\begin{array}{l}\text { PCV } \\
(\%)\end{array}$} & \multirow{2}{*}{$\begin{array}{l}\text { ECV } \\
\text { (\%) }\end{array}$} & \multirow{2}{*}{$\begin{array}{l}\mathrm{H}_{2} \text { bs } \\
(\%)\end{array}$} & \multirow[t]{2}{*}{ GA } & \multirow{2}{*}{$\begin{array}{c}\text { GAM } \\
(\%)\end{array}$} \\
\hline & & & GV & PV & EV & & & & & & \\
\hline $\begin{array}{l}\text { Seed cotton yield } \\
\text { plant }^{-1}\end{array}$ & $72.51 \pm 2.26$ & $19.17-125.68$ & 389.07 & 404.35 & 15.28 & 27.07 & 27.60 & 5.36 & 96.00 & 39.86 & 54.70 \\
\hline No. of bolls & $35.67 \pm 1.86$ & $9.80-60.93$ & 79.14 & 89.50 & 10.36 & 24.84 & 26.41 & 8.93 & 88.00 & 17.23 & 48.12 \\
\hline Boll weight boll- ${ }^{-1}$ & $2.18 \pm 0.07$ & $1.91-2.46$ & 0.01 & 0.03 & 0.01 & 4.88 & 7.18 & 5.27 & 46.00 & 0.15 & 6.84 \\
\hline No. of seeds boll-1 & $28.78 \pm 0.67$ & $25.00-33.00$ & 2.20 & 3.53 & 1.33 & 5.16 & 6.53 & 4.01 & 62.00 & 2.41 & 8.39 \\
\hline Seed index & $4.35 \pm 0.21$ & $3.38-5.39$ & 0.13 & 0.26 & 0.13 & 8.42 & 11.76 & 8.20 & 51.00 & 0.54 & 12.42 \\
\hline Lint index & $3.23 \pm 0.23$ & $2.38-4.23$ & 0.06 & 0.23 & 0.16 & 7.65 & 14.74 & 12.60 & 27.00 & 0.26 & 8.18 \\
\hline Ginning outturn & $41.25 \pm 1.10$ & $33.27-46.62$ & 5.11 & 8.73 & 3.62 & 5.49 & 7.17 & 4.62 & 59.00 & 3.56 & 8.65 \\
\hline No. of monopod & $3.81 \pm 0.29$ & $2.47-5.13$ & 0.24 & 0.50 & 0.26 & 12.95 & 18.56 & 13.29 & 49.00 & 0.71 & 18.60 \\
\hline Plant height & $177.70 \pm 5.26$ & $156.00-206.33$ & 124.46 & 207.46 & 83.00 & 6.28 & 8.11 & 5.13 & 60.00 & 17.80 & 10.02 \\
\hline Days to first flower & $75.65 \pm 0.99$ & $71.30-83.33$ & 3.52 & 6.47 & 2.95 & 2.48 & 3.36 & 2.27 & 54.00 & 2.85 & 3.77 \\
\hline Gossypol content & $0.53 \pm 0.03$ & $0.26-0.73$ & 0.01 & 0.017 & 0.00 & 23.08 & 24.55 & 8.37 & 88.00 & 0.24 & 44.70 \\
\hline Oil content & $16.95 \pm 0.25$ & $14.02-19.88$ & 1.304 & 1.485 & 0.18 & 6.74 & 7.19 & 2.51 & 88.00 & 2.21 & 13.01 \\
\hline Protein content & $13.27 \pm 0 . .40$ & $9.69-17.81$ & 3.88 & 4.35 & 0.47 & 14.81 & 15.70 & 5.19 & 89.00 & 4.91 & 28.81 \\
\hline
\end{tabular}

GV: Genotypic variance; PV: Phenotypic variance; EV: Environmental variance; GCV: Genotypic coefficient of variation; PCV: Phenotypic coefficient of variation; ECV: Environmental coefficient of variation; $\mathrm{H}_{2}$ bs: Heritability broad sense; GA: Genetic advance and GAM (\%): Genetic advance as \% of mean

and Kale and Annapurve (2007). Boll weight is crucial trait in deciding seed cotton yield. The range varied for this trait was observed 1.91 to $2.96 \mathrm{~g}$ with mean boll weight of $2.18 \mathrm{~g}$. The GCV (4.88\%) and PCV (7.18\%) were lower, similar result was reported by Khan et al. (2009); Ranjan et al. (2014). The low heritability $(46.00 \%)$ coupled with low GAM (6.84\%) indicating the presence of lower additive genetic variance so, it misleading in selection. No. of seeds Boll ${ }^{-1}$ reported as low variation and varied from 25.00 to 33.00 with mean 28.78 and low GCV, PCV, heritability and genetic advance, similarly for lint index and seed index. The GCV $(8.42 \%$ and 7.65\%) and PCV (11.76\% and $14.74 \%)$ for seed index and lint index respectively, was narrow indicating lesser role of environment. PCV and GCV are in agreement with Ranjan et al. (2014).Ginning outturn the range for this trait was wide ranging from 33.27 to $46.62 \%$ with a mean value of $41.25 \%$. Lower PCV (7.17) and GCV (5.49) values observed for this trait indicated low variability among the genotypes with moderate heritability $(49.80 \%)$ for this trait. Further, GAM was found to be low $(8.30 \%)$ indicating the predominance of non-additive genetic variance and hence selection will not be of any use. Similar reports of low heritability and low GAM were made by earlier workers Sambamurthy et al. (2006); Ranjan et al. (2014). The range for No. monopods plant ${ }^{-1}$ was varied from 2.47 to 5.13 with a mean value of 3.81. The PCV and GCV were observed to be moderate. Similar results have been reported by Sambamurthy and Rao (1998), Do Thi et al. (2008); Kulkarni et al. (2011); Ranjan et al. (2014). However, the heritability $(49.00 \%)$ was lower with low GAM $(18.60 \%)$ indicating the presence of higher genetic variance. The similar results were confirmation with Patnaik and Sial (2010). Plant height is one of the important traits, which influences final yield of the crop. Its range was variable accounting from $156.00 \mathrm{~cm}$ to 206.33 $\mathrm{cm}$ with the mean value of $177.70 \mathrm{~cm}$. The differences were narrow between PCV and GCV indicating that most of the variability was observed due to the predominance of genotype in the ultimate expression of the phenotype. Similar reports of varying levels of PCV and GCV in cotton were made by Do Thi et al. (2008), Patnaik and Sial (2010); Ranjan et al. (2014). This trait showed higher heritability $(60.00 \%)$ with moderate GA (17.80) and GAM (10.02). Similar results have been made by Sambamurthy et al. (2006); Do Thi et al. (2008); Patnaik and Sial (2010); Ranjan et al. (2014). Among biochemical parameters gossypol content is important trait which deciding level gossypol and reducing amount of gossypol is good for use cotton seed oil as gossypol free edible oil. The range for this trait was observed $0.26 \%-0.73 \%$ with mean value $0.53 \%$. The small differences between GCV (23.08\%) and PCV values $(24.55 \%)$ were indicating less influence of environment on this trait and variability was observed due to the genetic components. The higher heritability $(88.00 \%)$ coupled with high GAM $(44.70 \%)$ indicating the presence of additive genetic variance. Oil content is varied from $14.02 \%-19.88 \%$ with mean value $16.95 \%$. Small differences reported between GCV $(6.74 \%$ and PCV $(7.19 \%)$ and higher heritability $(88.00 \%)$. Similar result reported by Pandey (1977); Singh and Singh (1983); Narayanan et al. (1988); Erande et al. (2014). Protein content was varied from $9.69 \%-17.81 \%$ with mean value is $13.27 \%$. 
Narrow variation between GCV (14.81\%) and PCV (15.70\%) indicating that most of the variability is due to the genetic component and less influences of environment factor. Protein content showed higher heritability $(89.00 \%)$ with moderate GA (4.91) and higher GAM (28.81\%). Similar results have been made by Ashokkumar and Ravikesavan (2009).

The values of phenotypic variance were more than genotypic variance for all characteristics. High genotypic and phenotypic variance are observed for the characters like seed cotton yield, No. of bolls plant ${ }^{-1}$, plant height and days to $50 \%$ flowering. low genotypic and phenotypic variance are observed for the characters like gossypol content, boll weight plant ${ }^{-1}$, lint index, seed index, No. of monopods plant ${ }^{-1}$ etc. similar results reported by Erande et al. (2014). High GCV and PCV (>20\%) was observed for seed cotton yield plant ${ }^{-1}$, No. of bolls/plant and gossypol content and moderate GCV and PCV (10\% to $20 \%)$ was observed for No. of monopods and protein content and remaining all traits are reported as lowest GCV and PCV according to classes suggested by Sivasubramanian and Madhavamenon (1973) and conformation of results have been made by Erande et al. (2014). In present investigation through the PCV were greater than GCV. The differences between them are magnitude very small, that is, they were more or less close to each other. This indicates that there are small effects of environment on characters and selection may be effective. Heritability values are useful in predicting the expected progress to be achieved through the process of selection. Genetic coefficient variation along with heritability estimate provides a reliable estimate of the amount of genetic advance to be expected through phenotypic selection. According to singh (2001) heritability values greater than $80 \%$ are very high, values from 60 to $79 \%$ are moderately high and values from 40 to $59 \%$ are low. Characters were showed very high heritability like, seed cotton yield/plant, No. of bolls/ plant, gossypol content, oil content and protein content. Plant height and No. of seed boll-1 reported moderately high heritability performance and remaining all traits exhibited low heritability. Highest genetic advance reported traits were seed cotton yield plant ${ }^{-1}$, followed by No. of bolls plant ${ }^{-1}$ and plant height. High heritability estimates coupled with high expected genetic advance as percent mean were observed for the traits like, seed cotton yield plant ${ }^{-1}$, No. of bolls plant ${ }^{-1}$ and gossypol content. High heritability estimates with low genetic advance as percent of mean were observed for oil content, protein content, No. of seeds boll-1 and plant height that indicating presence of non additive gene action. Low heritability estimates with expected low genetic advance were observed for the traits like Lint index, Boll weight boll-1 and seed index confirmation of results have made by Erande et al. (2014).

\section{Conclusion}

Characters having high GCV, PCV, heritability, coupled with high genetic advance as percent of mean that indicating presence of additive gene effects in its inheritance and such characters could be improved by selection. Whereas low heritability and low genetic advance also indicates greater role of non-additive gene action in their inheritance suggesting heterosis breeding could be useful for improving these traits.

\section{Acknowledgement}

The authors acknowledge the support given by CCSHAU and Deptt. of Genetics and Plant Breeding, Cotton Section and ICAR for providing a postgraduate scholarship. We are also grateful to the group of cotton scientist of cotton section, CCSHAU, Hisar, India.

\section{References}

Ashok kumar, K., Ravikesavan, 2009. Understanding the genetic variability of seed oil, seed protein and seed index traits in upland cotton. (G. hirsutum L.). Souvenir. International conference on "Emerging trends in production, processing and utilization of natural fibres, Mumbai, India, 42-48.

Dhamayanathi, K.P.M., Manickam, S., Rathinavel, K., 2010. Genetic variability studies in Gossypium barbadense L., genotypes for seed cotton yield and its yield components. Electronic Journal of Plant Breeding, 1(4), 961-965.

Do Thi ha an, Ravikesavan, R., lyanar, 2008. Genetic advance and heritability as a selection index for improvement of yield and quality cotton. Journal of Cotton Research and Development 22(1), 14-18.

Erande, C.S., Kalpande, H.V., Deosarkar, D.B., Chavan, S.K., Patil, V.S., Desmukh, J.D., Chinchane, V.N., Anil, K., DEY, U., Puttawar, M.R., 2014. Genetic variability, correlation and path analysis amomg different traits in desi cotton (G. arboreum L.). African Journal of Agricultural Research 9(29), 2278-2286.

Falconer, D.S., 1981. Introduction of Quantitative Genetics, Longman Inc. Ltd., New York.

Hanson, C.H., Robinson, H.F., Comstock, R.E., 1956. Biometrical studies of yield and segregating populations of Korean lespedza. Agronomy Journal, 47, 313-318.

Hutchinson, J.B., 1940. The application of genetics to plant breeding. I. The genetic interpretation of plant breeding problems. Journal of Genetics, 40, 271-282.

Johanson, H.W., Robinson, H., Comstock, R.E., 1955. Estimates of genetic and environmental variability in soybean. Agronomy Journal, 47, 314-318.

Kale, U.V., Annapurve, 2007. Yield components analysis in American cotton (G. hirsutum L.), Madras Agricultural Journal, 94, 156-161.

Kaushik, S.K., Kapoor, C.J., 2006. Genetic variability and association study for yield and its component traits in upland cotton (Gossypium hirsutum L.). Journal of Cotton Research and Development 20(2), 185-190.

Khan, B.M., Khan, N.U., Khan, I., 2009. Genetic variability and 
heritability in upland cotton. Pakistan Journal of Botany 41(4), 1695-1705.

Kulkarni, A.A., Nanda, H.C., Patil, S.G., 2011. Studies on genetic divergence in upland cotton (Gossypium hirsutum L.). Journal of Cotton Research and Development 25(1), 9-13.

Miller, P.A., Williams, J.C., Robinson, H.F., Comstock, R.R., 1958. Estimates of genotypic and environmental variance and covariance in upland and their implications in selection. Agronomy Journal 50, 126-131.

Narayanan, S.S., Singh P., Singh V.V., 1988. Effects of disruptive selection on seed oil content in upland cotton. Indian Journal of Agricultural Science 58(5), 399-400.

Pandey, S.N., 1977. Utilization of cotton seed and its products. Cotton Development 7(1), 4-9.

Patnaik, R.K., Sial, P., 2010. Genetic variability, character association and component analysis in upland cotton (Gossypium hirsutum L.) under rainfed condition. Journal of Cotton Research and Development 24(2), 155-159.

Ranjan, R., Sangwan, R.S., Siwach, S.S., Sangwan, O., Sah, M.K., 2014. Studies of genetic parameters for seed cotton yield and its contributing characters in Gossypium arboreum L. Journal of Cotton Research and Development 28(2) 227-229.
Sambamurthy, J.S.V., Rao, B.R., 1998. Genetic variability and association analysis in parents and hybrids of American cotton. Journal of Cotton Research and Development 12(2), 236-241.

Sambamurthy, J.S.V., Ratna Kumari, S., Chamundeshwari, N., 2006. Studies on variability correlation path analysis over environments (Gossypium herbaceum L.) cotton under coastal saline soils. Journal Maharashtra Agriculture University 31(1), 60-64.

Singh, B.D., 2001. Plant breeding: principles and methods. Kalyani publishers, New Delhi, India, 896.

Singh, P., Singh, V.V., 1983. Variability for seed oil content in diploid genetic stocks of cotton. Current Science 52(19) 928-929.

Sivasubramanian, V., madhavamenon, P., 1973. Path analysis for yield and yield components of rice. Madras Agricultural Journal, 60, 1217-1221.

Sunayana, Sangwan, R.S., Nimbal, S., 2017. Studies on Association, Path Analysis and Genetic Parameters for Seed Cotton Yield and Its Contributing Characters in Desi Cotton (Gossypium arboreum L.). International Journal of Current Microbiology and Applied Sciences, 6(11), 104-111. 